\begin{tabular}{|c|c|c|}
\hline $\begin{array}{l}\text { OPEN ACCESS } \\
\text { Vol. } 4 \text { No. 1: } 28-34 \\
\text { Tahun 2020 } \\
\text { Artikel penelitian 直 }\end{array}$ & 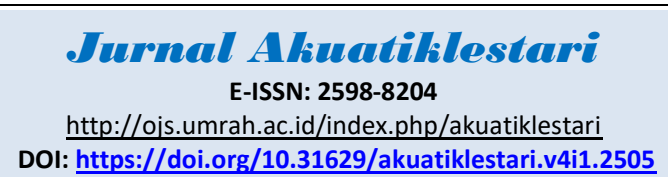 & 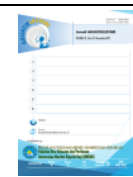 \\
\hline
\end{tabular}

\title{
Hubungan Panjang Berat Tiga Jenis Ikan Introduksi yang Tertangkap di Waduk Penjalin Kabupaten Brebes
}

\author{
Relationship of Long Weight Three Types of Instructed Fish Captured in Reservoir Penjalin Brebes \\ District
}

\section{Dewi Kresnasari ${ }^{1 凶}$}

${ }^{1}$ Fakultas Sains dan Teknologi, Universitas Nahdlatul Ulama, Purwokerto, Indonesia

\section{$\square$ Info Artikel:}

Diterima: 31 Agustus 2020

Revisi: 5 September 2020

Disetujui: 7 Oktober 2020

Dipublikasi: 30 November 2020

\section{(口) Keyword: \\ Pola Pertumbuhan, Faktor Kondisi, Ikan Introduksi, Waduk Penjalin}

$\bowtie$ Penulis Korespondensi: Dewi Kresnasari

Fakultas Sains dan Teknologi, Universitas Nahdlatul Ulama Email: dewiks2903@gmail.com

\begin{abstract}
ABSTRAK.
Keberadaan populasi ikan introduksi di Waduk Penjalin semakin bertambah banyak. Populasi ikan introduksi ini diduga akan mempengaruhi ekosistem di waduk tersebut. Oleh karena itu, perlu dilakukan penelitian untuk mengevaluasi pola pertumbuhan dan faktor kondisi ketiga jenis ikan introduksi yaitu Ikan Betutu (Oxyeleotris marmorata), Ikan Marsela (Parachromis managuensis) dan Ikan Nila (Oreochromis niloticus). Pengambilan sampel dilakukan secara simple random sampling pada bulan September - Oktober 2018. Sebanyak 40 ekor dari masing-masing spesies diukur panjang dan beratnya. Analisis data pola pertumbuhan pada masing-masing jenis ikan menggunakan persamaan Linear Allometric Model (LAM), dan untuk faktor kondisi dianalisis dengan menggunakan indeks pondreal. Hasil penelitian menunjukkan bahwa Ikan Betutu (Oxyeleotris marmorata) dan Ikan Nila (Oreochromis niloticus) mempunyai pola pertumbuhan allometrik negatif, sementara Ikan Marsela (Parachromis managuensis) mempunyai pola pertumbuhan isometrik. Selain itu, faktor kondisi ketiga jenis ikan tersebut menunjukkan angka diatas satu yang berarti bahwa ketiga jenis ikan tersebut dalam keadaan baik dan dapat untuk dikonsumsi.
\end{abstract}

\begin{abstract}
.
The existence of introduced fish populations in Penjalin Reservoir is increasing. This introduced fish population is expected to affect the ecosystem in the reservoir. Therefore, research is needed to evaluate the growth patterns and condition factors of the three types of fish introduced, namely Betutu Fish (Oxyeleotris marmorata), Marsela Fish (Parachromis managuensis) and Tilapia Fish (Oreochromis niloticus). Sampling was carried out by simple random sampling in September - October 2018. A total of 40 head of each species measured length and weight. Data analysis of growth patterns for each fish type using the Linear Allometric Model (LAM) equation, and for the condition factor analyzed using the pondreal index. The results showed that Betutu Fish (Oxyeleotris marmorata) and Tilapia (Oreochromis niloticus) had negative allometric growth patterns, while Marsela fish (Parachromis managuensis) had isometric growth patterns. In addition, the condition factor of the three types of fish shows a number above one which means that all three types of fish are in good condition and can be consumed.
\end{abstract}

周 How to cite this article:

Kresnasari, D. (2020). Hubungan Panjang Berat Tiga Jenis Ikan Introduksi yang Tertangkap di Waduk Penjalin Kabupaten Brebes. Jurnal Akuatiklestari, 4(1): 28-34. https://doi.org/10.31629/akuatiklestari.v4i1.2505

\section{PENDAHULUAN}

Provinsi Jawa tengah mempunyai salah satu waduk yang mendukung produktifitas perikanan yaitu Waduk Penjalin. Waduk ini terletak di Desa Winduaji, Kecamatan Paguyangan, Kabupaten Brebes, Jawa Tengah. Sumber air waduk tersebut berasal dari aliran sungai Penjalin, Soka, dan Garung (Hedianto et al. 2013). Waduk Penjalin mempunyai fungsi sebagai tempat penampungan air pada saat musim hujan dan saat musim kemarau dapat digunakan untuk berbagai kepentingan, seperti air minum, irigasi, pengendalian banjir, periwisata, kegiatan perikanan tangkap dan budidaya (Mukhroji \& Suprapto, 2018).

Ketersediaan ikan di Waduk Penjalin dari tahun ke tahun mengalami penurunan, hal ini dapat dilihat dari jumlah ikan dan jumlah spesies yang tertangkap pada tahun 2011. Penelitian yang dilakukan oleh Rukayah \& Wibowo (2011) di Waduk Penjalin terdapat 27 spesies yang tertangkap dan didominasi oleh Ikan Nila (Oreochromis niloticus), sedangkan 
pada tahun 2013, ikan yang tertangkap berjumlah 6 spesies, yaitu ikan Manila (Parchromis managuensis), Betutu (Oxyeleotris marmorata), Nila (Oreochromis niloticus), Nilem (Osteochilus vittatus), Tawes (Barbonymus gonionotus), dan Beunteur (Puntius binotatus), dan didominasi oleh ikan Manila atau Marsela (Parachromis managuensis) sebanyak 129 ekor (Hedianto et al., 2013).

Memasukkan ikan spesies baru ke dalam suatu perairan dimana sebelumnya tidak terdapat spesies tersebut disebut kegiatan introduksi ikan (Sentosa et al., 2013). Ikan masuk ke dalam suatu badan perairan dapat terjadi secara sengaja atau tidak disengaja (Syafei \& Sudinno, 2018). Keberadaan Ikan introduksi pada suatu badan perairan memiliki dampak positif dan negatif, namun berdasarkan pengalaman, dampak yang diperlihatkan cenderung bersifat merugikan, terutama terkait keanekaragaman ikan. Menurut Hedianto et al., (2013), Ikan Betutu (O. marmorata), Ikan Marsela (P. managuensis) dan Ikan Nila (O. niloticus) adalah termasuk ikan introduksi di daerah Waduk Penjalin. Kehadiran Ikan tersebut dikhawatirkan memiliki dampak negatif terhadap organisme lain terutama ikan asli. Hasil analisis dari 31 studi kasus introduksi ikan asing ke perairan sungai menunjukkan bahwa 77\% introduksi ikan asing mengakibatkan penurunan populasi ikan asli (Wargasasmita, 2005). Penurunan populasi merupakan proses awal yang berakibat pada menurunnya keanekaragaman hayati dan berakhir dengan terbentuknya komunitas ikan yang homogen dan didominasi oleh ikan asing. Dampak negatif lainnya yaitu terjadinya kompetisi pakan dan habitat, pemangsaan dan parasit atau penyakit. Menurut penelitan Atikah et al. (2019) di Waduk Penjalin lebih banyak ditemukan ikan yang bersifat omnivora karnivora dibandingkan ikan omnivora herbivora. Hal ini dapat mengakibatkan keanekaragaman beberapa jenis ikan pada tingkat trofik dibawahnya menurun sehingga keseimbangan ekosistem terganggu.

Upaya pengendalian spesies introduksi dapat dilakukan melalui pengendalian habitat melalui pemantauan kondisi fisika dan kimia perairan. Selain itu, pengendalian dapat dilakukan melalui pengendalian produksi dengan predasi, kompetisi, fekunditas yang tinggi dan alat tangkap yang digunakan sehingga diharapkan mampu mengendalikan kelimpahan dan indukan ikan introduksi.

Namun demikian penelitian tentang aspek biologi ikan introduksi yang tertangkap di Waduk Penjalin belum banyak dikaji. Keberadaan ikan introduksi perlu dikaji untuk mempertahankan kelestarian spesies asli dan keseimbangan ekosistem. Dalam kaitan itu perlu diketahui informasi mengenai aspek biologi beberapa spesies ikan introduksi yang terdapat di Waduk tersebut. Beberapa penelitian telah dilakukan di Waduk Penjalin. Salah satunya mengenai kebiasaan makan dan luas relung ikan-ikan indigenous (Elinah et al., 2017). Selain itu Hedianto et al. (2013), melaporkan bahwa interaksi komunitas ikan dalam memanfaatkan pakan alami cenderung memiliki komunitas yang rendah akiat tingginya tingkat predasi. Adapun tujuan dari penelitian ini adalah untuk mendapatkan informasi mengenai hubungan panjang berat dan faktor kondisi ikan introduksi sehingga dapat dijadikan dasar pengelolaan ikan introduksi, terutama di Waduk Penjalin. Pengelolaan yang sesuai ditujukan agar sumberdaya ikan di waduk tersebut dapat dimanfaatkan secara optimal tanpa menggangu keseimbangan ekosistem

\section{BAHAN DAN METODE}

\subsection{Waktu dan tempat}

Penelitian ini dilaksanakan pada bulan September - Oktober 2018. Bertempat di Waduk Penjalin, Kabupaten Brebes (Gambar 1).

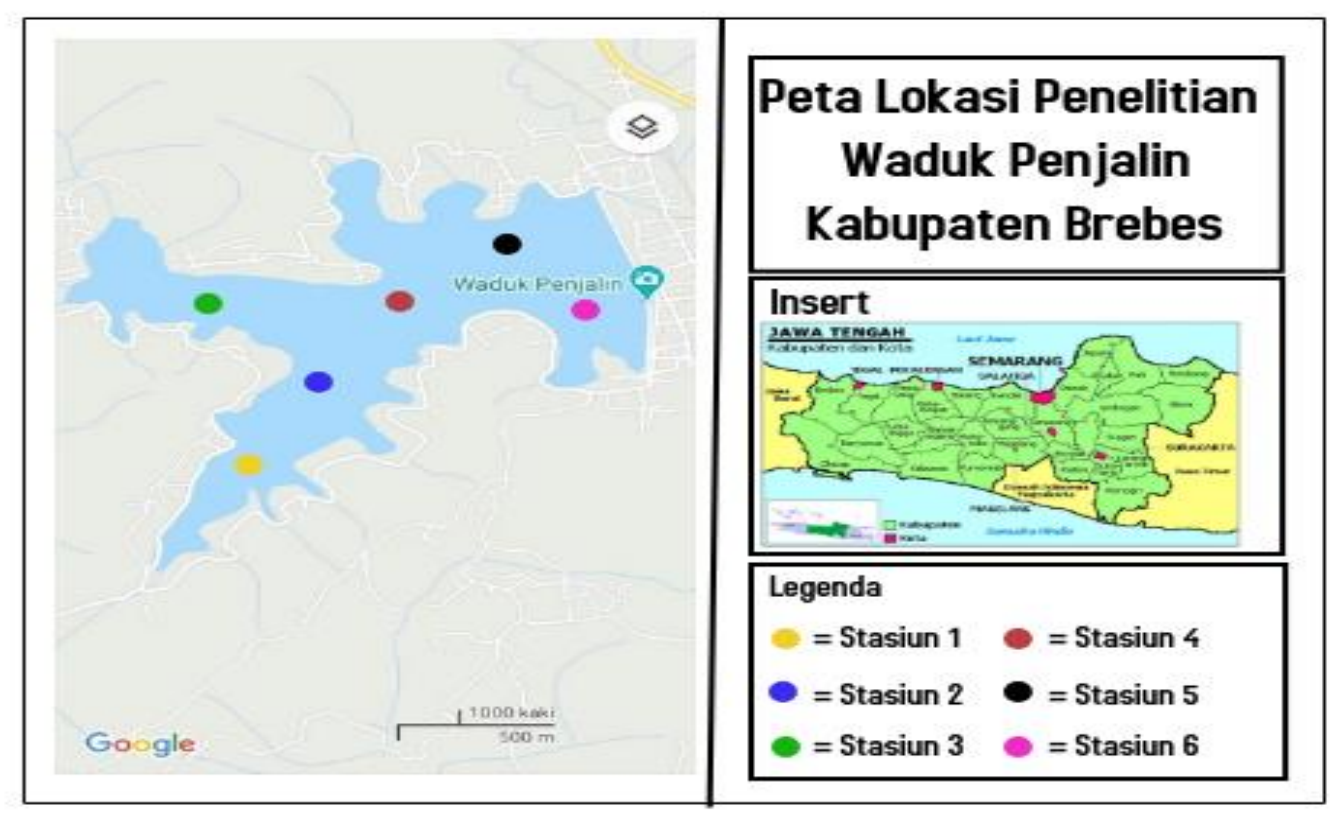

Gambar 1. Peta Lokasi Penelitian 


\subsection{Alat dan bahan}

Hasil tangkapan ikan sampel yang didapat selama penelitian diperoleh dengan menggunakan jaring insang dengan ukuran mata 2-4 inci. Ikan yang tertangkap diukur panjang dan beratnya. Pengukuran panjang total (total length) diukur dengan menggunakan milimeter blok dengan ketelitian $1 \mathrm{~mm}$ dan pengukuran berat menggunakan timbangan ketepatan $0,1 \mathrm{~g}$.

\subsection{Prosedur penelitian}

Ikan sampel diambil dengan menggunakan jaring secara Simple Random Sampling dari hasil tangkapan. Pengambilan sampel ikan dalam satu hari dilakukan sebanyak 6 kali yaitu pada pukul 05:00, 11:00, 17:30, 21:00, 00:00, dan 03:00.

\subsection{Teknik pengumpulan data}

Ikan sampel dipisahkan berdasarkan jenisnya. Setelah itu diukur panjang total ikan dengan menggunakan millimeter blok dan bobotnya dengan menggunakan timbangan. Data yang terkumpul dapat digunakan untuk memnentukan panjang dan berat ikan serta faktor kondisi.

\subsection{Analisis data}

\subsubsection{Hubungan panjang berat ikan}

Hubungan panjang berat ikan di analisa menggunakan persamaan Linear Allometric Model (LAM) sebagai berikut :

$$
\mathrm{W}=\left(a L^{b}\right)
$$

Keterangan :

W adalah berat ikan (g), L adalah panjang ikan ( $\mathrm{cm}$ ), a adalah intercept regresi linear, b adalah koefisien regresi. Nilai b dari hasil perhitungan ini dapat mencerminkan pola pertumbuhan ikan. Jika nilai $b=3$, maka pola pertumbuhan bersifat isometric atau pertambahan berat setara dengan pertumbuhan panjang ikan dan jika nilai $b \neq 3$, maka pola pertumbuhannya bersifat allometric. Pola pertumbuhan allometric terbagi menjadi dua, yaitu allometric positif dan allometric negative. Jika nilai $b<3$ disebut allometric negative (pertambahan panjang lebih cepat dibandingkan dengan pertambahan berat), dan bila nilai $b>3$ disebut allometric positif (pertambahan berat lebih cepat dibandingkan dengan pertambahan panjang) (Effendie, 2002).

\subsubsection{Faktor kondisi}

Faktor kondisi sering disebut juga dengan faktor K. Nilai ini merupakan terapan dari analisa hubungan panjang berat ikan dan merupakan derivat yang penting dalam pertumbuhan ikan. Baik tidaknya kondisi ikan dilihat dari segi kapasitas fisik untuk kelangsungan hidup dan reproduksi dapat digambarkan dari nilai faktor kondisi.

Perhitungan faktor kondisi dilakukan dengan menggunakan persamaan Ponderal index. Berdasarkan hasil analisis hubungan panjang berat, apabila diperoleh nilai $\mathrm{b} \neq 3$, (pola pertumbuhan allometrik) maka faktor kondisi dihitung menggunakan rumus yang dikemukakan oleh Effendie (1997):

$$
\mathrm{K}=\frac{\mathrm{W}}{\mathrm{aL}^{\mathrm{b}}}
$$

Apabila dari hasil perhitungan yang didapat adalah nilai $\mathrm{b}=3$ (pola pertumbuhan isometrik), maka faktor kondisi dihitung dengan rumus:

$$
\mathrm{K}=\frac{\mathrm{W}}{\mathrm{L}^{3}} \times 10^{5}
$$

\section{Keterangan :}

$\mathrm{K}=$ faktor kondisi; $\mathrm{W}$ = berat total ikan (gr); $\mathrm{L}=$ panjang total ikan (mm); $10^{5}=$ Konstanta agar $\mathrm{K}$ mendekati $\mathrm{l}$; $\mathrm{a}$ dan $\mathrm{b}=$ konstanta; Harga $10^{5}$ dari rumus diatas diambil sedemikian rupa sehingga nilai K mendekati l. Harga satuan K sendiri tidak berarti apa-apa, akan tetapi terlihat kegunaanya apabila dibandingkan dengan individu lainnya antara satu grup dengan grup lainnya. Jika nilai K berkisar antara 2-4 maka badan ikan itu tergolong agak pipih, sedangkan ikan-ikan yang badannya kurang pipih nilai K berkisar antara l-3.

\section{HASIL DAN PEMBAHASAN}

Berdasarkan hasil penelitian yang telah dilakukan, terdapat tiga spesies ikan introduksi yaitu Ikan Betutu (O. marmorata) (Gambar 2A), Ikan Marsela (P. managuensis) (Gambar 2B) dan Ikan Nila (O. niloticus) (Gambar 2C). Hasil pengukuran parameter morfometrik Ikan Betutu (O. marmorata), Ikan Marsela (P. managuensis) dan Ikan Nila (O. niloticus) dapat dilihat pada Tabel 1. 

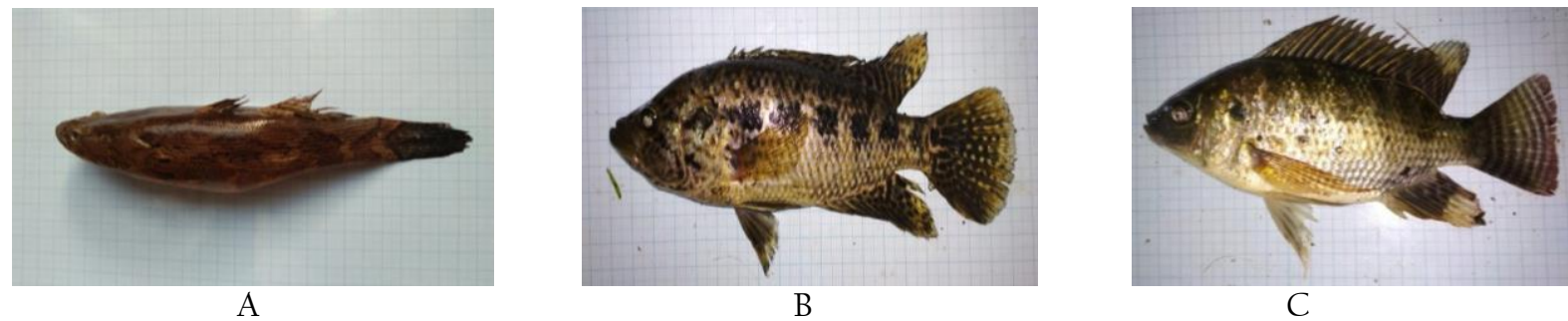

Gambar 2. A. Ikan Betutu (O. marmorata); B. Ikan Marsela (P. managuensis); C. Ikan Nila (O. niloticus)

Tabel 1. Parameter yang diukur pada Ikan Betutu (O. marmorata), Ikan Marsela (P. managuensis) dan Ikan Nila (O.niloticus)

\begin{tabular}{llll} 
Parameter & Ikan Betutu & Ikan Marsela & Ikan Nila \\
Panjang total $(\mathrm{cm})$ & $6,7-26$ & $9,7-20$ & $9-40$ \\
Berat $(\mathrm{g})$ & $16,9-222$ & $14,2-127,2$ & $15-1126$ \\
Nilai b & 2,132 & 3,086 & 2,87 \\
& $(\mathrm{~b}<3)$ & $(\mathrm{b}=3)$ & $(\mathrm{b}<3)$ \\
Koefisien determinasi & 0,66 & 0,963 & 0,97 \\
Faktor Kondisi & $1,0-2,3$ & $1,2-1,9$ & $1,2-2,5$ \\
\hline
\end{tabular}

Ikan Betutu (O. marmorata) yang tertangkap selama penelitian memiliki panjang total 6,7-26 $\mathrm{cm}$ dan berat 16,9 $222 \mathrm{~g}$ (Tabel 1). Berdasarkan analisis regresi panjang dan berat ikan menghasilkan persamaan $\mathrm{Y}=2,1329 \mathrm{X}-0,9041$ (Gambar 3). Dari hasil tersebut dapat diketahui nilai b < 3 yaitu 2,132. Ini menunjukan bahwa pola pertumbuhan Ikan Betutu (O. marmorata) bersifat allometrik negatif yang berarti pertumbuhan panjang ikan lebih cepat dibanding berat ikan. Koefisien determinasi ( $\mathrm{R}^{2}$ ) Ikan Betutu (O. marmorata) sebesar 0,66. Pada nilai tersebut pertambahan berat Ikan Betutu (O. marmorata) sebesar 66\% disebabkan oleh pertambahan panjang, sedangkan 34\% disebabkan oleh faktor lain. Selanjutnya nilai ini menggambarkan panjang total tubuh tidak terlalu mempengaruhi berat Ikan Betutu (O. marmorata).

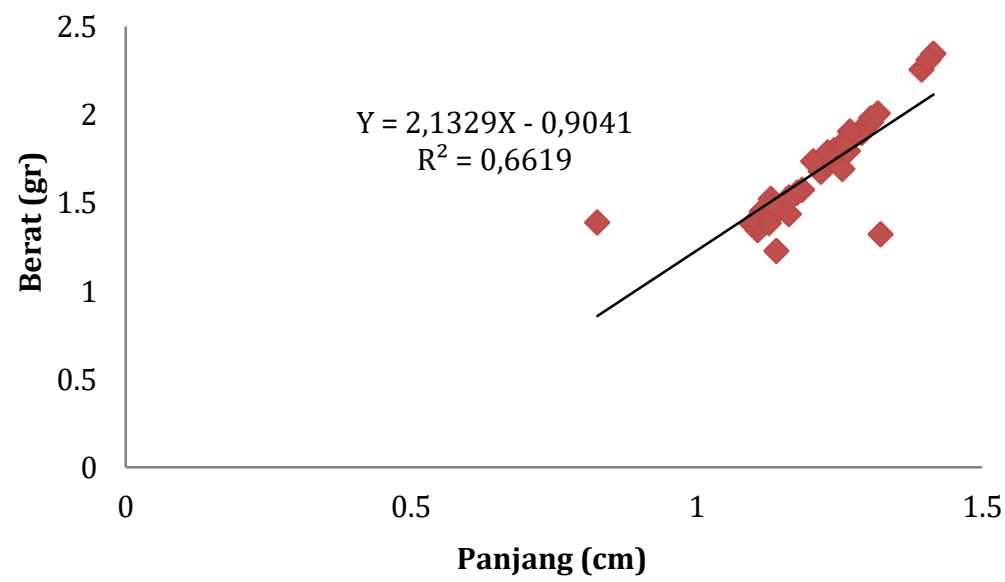

Gambar 3. Hubungan panjang berat Ikan Betutu (O. marmorata)

Ukuran Ikan Betutu (O.marmorata) yang diperoleh selama penelitian hampir sama dengan penelitian yang telah dilakukan Hedianto (2013), yaitu panjang total 8,6 - 24,5 cm dan berat 8,5 - 198,5 g. Akan tetapi berbeda dengan ukuran Ikan Betutu (O. marmorata) pada perairan Aceh, yaitu Sungai Meunasah Kumbang memperoleh panjang total Ikan Betutu (O. marmorata) sebesar 6,4-12,9 cm dengan berat 3,93- 30,33 g, sedangkan di Sungai Balee Ulim memperoleh panjang total 6,8-11,5 cm dan berat 5,2-19,9 g (Nasir et al., 2016). Ukuran Ikan Betutu (O. marmorata) yang terdapat di Waduk Penjalin lebih besar dibanding dengan perairan Aceh. Hal ini diduga Waduk Penjalin menyediakan makanan dan lingkungan perairan yang cocok untuk kehidupan Ikan Betutu (O marmorata). Menurut Effendie (2002), ukuran ikan dipengaruhi oleh faktor ketersediaan makanan dan kondisi lingkungan perairan.

Berdasar hasil penelitian, panjang total Ikan Marsela (P. managuensis) berkisar 9,7 - $20 \mathrm{~cm}$ dan berat 14,2 - 127,2 g (Tabel 1). Pada analisis hubungan panjang dan berat ikan didapatkan persamaan Y =3,0862X - 1,904 (Gambar 4). Dari analisis tersebut diketahui nilai $b=3$ yaitu 3,0862. Ini menunjukan Ikan Marsela (P. managuensis) memiliki pola pertumbuhan isometrik yang berati bahwa pertumbuhan panjang sama dengan berat ikan. Koefisien determinasi ( $\left.\mathrm{R}^{2}\right)$ pada ikan ini sebesar 0,96. Selanjutnya nilai ini menggambarkan pertambahan berat ikan sangat dipengaruhi oleh panjang tubuhnya sebesar 96\%, sedangkan 4\% disebabkan oleh faktor lain. 


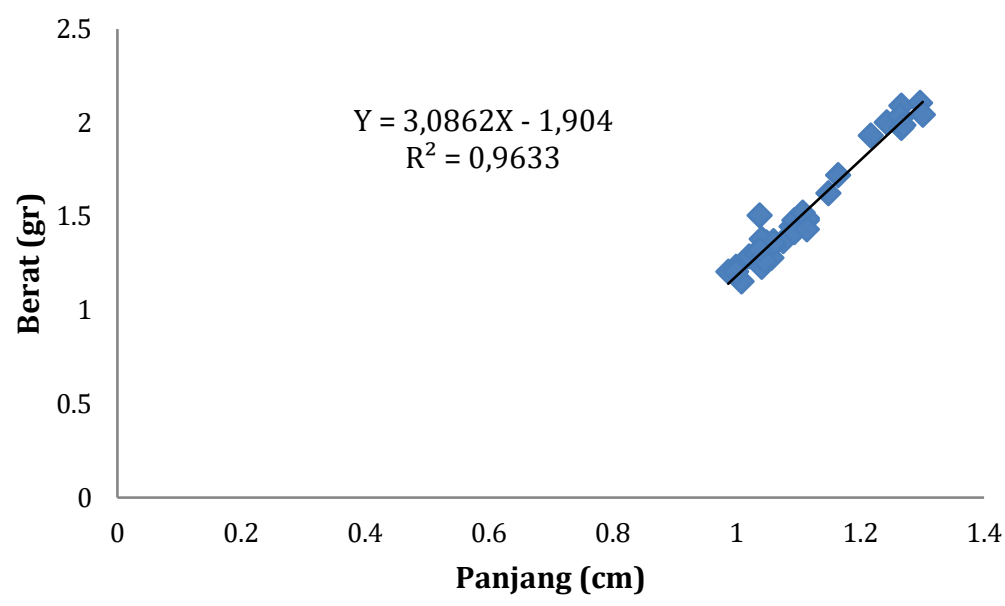

Gambar 4. Hubungan Panjang Berat Ikan Marsela (P. managuensis)

Pada penelitian sebelumnya di tempat yang sama, Hedianto et al. (2013) menyatakan bahwa ukuran Ikan Marsela (P. managuensis) yang tertangkap mempunyai panjang total 6,0 - 20,1 cm dengan berat 6,6 - 155,9 g. Selanjutnya Hamiyati (2016) mendapatkan panjang total Ikan Marsela (P. managuensis) $9-19,8 \mathrm{~cm}$ dengan berat 5 - $127 \mathrm{~g}$. Ukuran Ikan Marsela (P. managuensis) yang tertangkap di tempat yang sama dengan waktu yang berbeda menujukan hasil yang tidak jauh berbeda. Berbeda dengan penelitian Agasen et al. (2006) melaporkan bahwa panjang total maksimum Ikan Marsela (P. managuensis) yang tertangkap Sungai Canal, Florida yaitu 40,2 cm dan di Filipina berukuran 10,20 - 29,10 $\mathrm{cm}$. Ukuran Ikan yang tertangkap di Florida dan Filipina lebih besar dibanding Waduk Penjalin. Hal ini diduga faktor geografis mempengaruhi ukuran ikan.

Panjang total Ikan Nila (O. niloticus) selama penelitian yaitu $9-40 \mathrm{~cm}$ dan berat sebesar 15 - $1126 \mathrm{~g}$ (Tabel 1). Dari analisis regresi panjang dan berat ikan diperoleh persamaan $Y=2,87 X-1,525$ (Gambar 5). Hasil tersebut menunjukan bahwa nilai b < 3 yaitu 2,87. Ini berarti Ikan Nila (O. niloticus) memiliki pola pertumbuhan allometrik negatif dimana pertumbuhan panjang lebih cepat dibanding dengan berat ikan. Koefisien determinasi $\left(\mathrm{R}^{2}\right)$ yang diperoleh sebesar 0,97. Selanjutnya nilai ini menggambarkan pertambahan berat ikan sangat dipengaruhi oleh pertambahan panjang tubuh sebesar 97\%, sedangkan 3\% disebabkan oleh faktor lain.

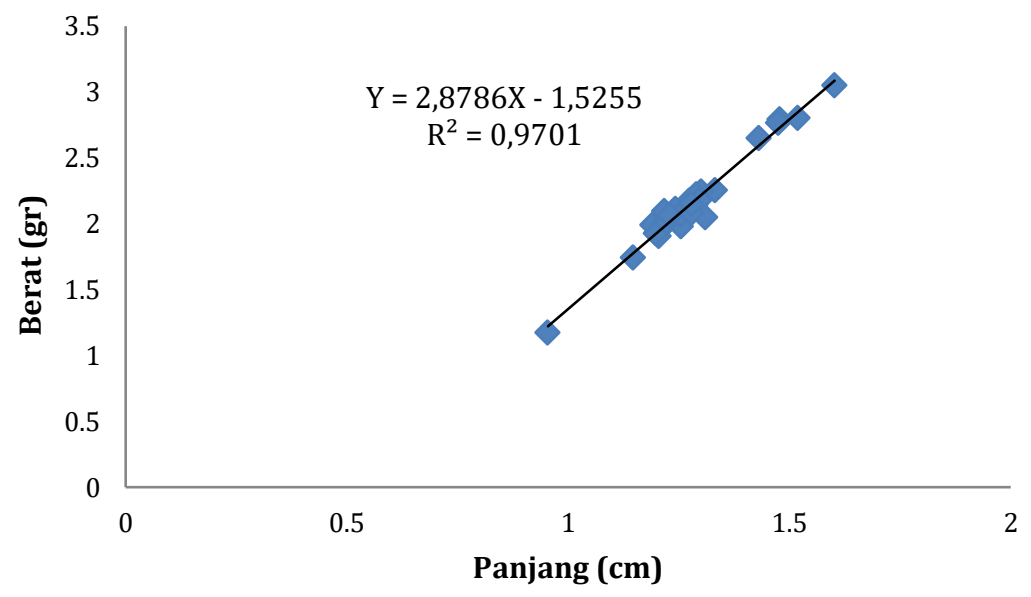

Gambar 5. Hubungan Panjang Berat Ikan Nila (O. niloticus)

Panjang total Ikan Nila (O. niloticus) pada penelitian sebelumnya di tempat yang sama yaitu 9,4-28 cm dan berat 14,1 - 435,1 g (Hedianto, 2013). Pada Waduk Ir. H.Djuanda panjang total Ikan Nila yang diperoleh berkisar $11-41 \mathrm{~cm}$ (Putri \& Tjahjo, 2010). Hal ini menunjukan bahwa ukuran Ikan Nila (O. niloticus) yang tertangkap pada saat penelitian lebih besar dibanding penelitian terdahulu. Diduga umur ikan dan masa reproduksi mempengaruhi ukuran ikan yang tetangkap.

\section{Pola Pertumbuhan}

Pola pertumbuhan Ikan Betutu (O. marmorata) yang diperoleh saat penelitian adalah allometrik negatif. Pola ini juga ditemukan pada perairan sungai di Aceh. Pada Sungai Meunasah Kumbang diperoleh nilai b sebesar 2,75 dan Sungai Balee Ulim sebesar 2,68 (Nasir et al., 2016). Hal ini diduga karena arus yang kuat pada dasar perairan. Menurut Lubis (2002), Ikan Betutu (O. marmorata) termasuk ikan demersal dan tipe perenang pasif. Akan tetapi karena besarnya arus bawah menyebabkan perbedaan alokasi energi yang dikeluarkan untuk pergerakan dan pertumbuhan. 
Ditambahkan pula oleh Mulfizar et al. (2012), bahwa ikan yang hidup diperairan arus deras umumnya memiliki nilai b yang lebih rendah dan sebaliknya ikan yang hidup pada perairan tenang akan menghasilkan nilai b yang besar. Selanjutnya untuk pola pertumbuhan Ikan Marsela (P. managuensis) selama penelitian adalah isometrik ( $b=3)$. Hasil ini berbeda dengan yang telah dilakukan oleh Hamiyati (2016), bahwa pada ikan Marsela (P. managuensis) mempunyai nilai b > 3 yaitu 3,37 yang berarti bahwa pola pertumbuhannya allometrik positif. Pola pertumbuhan Ikan Nila (O. niloticus) selama penelitian adalah allometrik negatif. Hasil allometrik negatif di peroleh juga di Sungai Matang Guru sebesar 1,30 (Muttaqin, 2016) dan 2,7 di Danau Buyan (Sravishta et al., 2018). Akan tetapi, pola pertumbuhan Ikan Nila (O. niloticus) di Waduk Jatiluhur pada tahun 2017 sebesar 3,09 (isometric) dimana pertumbuhan panjang sama dengan beratnya (Warsa \& Didik, 2019).

Secara umum perbedaan nilai b baik pada sesama spesies ataupun antar spesies diduga tergantung pada kondisi fisiologis, biologis, letak geografis, lingkungan serta teknik sampling. Menurut Muttaqin et al. (2016), meskipun berasal dari lokasi yang sama perbedaan nilai b yang diperoleh diduga karena perbedaan perkembangan gonad, ketersediaan makan dan kondisi lingkungan pada saat pengambilan sampel. Ditambahkan pula oleh Aprianti \& Khoirul (2015), bahwa hubungan panjang berat menunjukkan pertumbuhan yang bersifat relatif. Artinya yaitu memungkinkan dapat berubah menurut waktu. Apabila terjadi perubahan lingkungan dan ketersediaan makanan diperkirakan nilai ini juga akan berubah. Perubahan berat ikan dapat dihasilkan dari perubahan pakan dan alokasi energi untuk tumbuh dan reproduksi (Mahmudah et al., 2019). Hal ini yang mengakibatkan berat ikan berbeda walaupun panjangnya sama. Selanjutnya perbedaan nilai b juga dapat dipengaruhi oleh jenis kelamin (Sulistiono et al., 2001), perbedaan jumlah dan variasi ukuran ikan yang diamati (Fuadi, 2016).

\section{Faktor Kondisi}

Faktor kondisi adalah perbandingan antara berat ikan dengan pangkat tiga panjangnya merupakan faktor yang menggambarkan kondisi kegemukan ikan. Faktor kondisi menunjukkan keadaan ikan baik dilihat dari segi kapasitas fisik untuk survival maupun reproduksi (Brojo et al. 2001). Faktor kondisi penting bagi pemahaman siklus hidup ikan dan memberikan kontribusi pada pengelolaan ikan, dan dengan demikian memberikan kontribusi pada pengelolaan keseimbangan ekosistem (Rahardjo \&e Simanjuntak, 2008). Hasil perhitungan faktor kondisi untuk Ikan Betutu (O. marmorata) di Waduk Penjalin berkisar 1,01 - 2,3 ; Ikan Marsela (P. managuensis) berkisar 1,2 - 1,9 dan Ikan Nila (O. niloticus) berkisar 1,2 - 2,5.

Ketiga ikan tersebut mempunyai nilai faktor kondisi lebih dari satu. Hal ini mengindikasikan bahwa ikan yang diamati berada dalam kondisi baik dan dapat digunakan untuk konsumsi. Menurut Effendie (2002), Nilai faktor kondisi secara komersil mempunyai arti penting menentukan kualitas dan kuantitas daging ikan yang tersedia untuk dapat dimakan.

Nilai Faktor kondisi menurut Mahmudah et al., (2019), dapat digunakan ini mencerminkan karakteristik morfologi tubuh dan tingkat pertumbuhan. Selama penelitian Ikan Marsela (P. managuensis) mempunyai nilai faktor kondisi yang tergolong dalam kategori memiliki badan yang kurang pipih. Sedangkan untuk Ikan Nila (O. niloticus) dan Ikan Betutu (O. marmorata) termasuk kategori ikan dengan tubuh agak pipih. Menurut Effendie (2002), ikan dengan nilai faktor kondisi berkisar 2-4 memiliki tubuh yang agak pipih, sedangkan 1-3 untuk ikan yang memiliki badan yang kurang pipih.

Bervariasinya nilai faktor kondisi diduga terjadinya persaingan dalam memanfaatkan sumber makanan yang sama. Selain itu nilai kondisi kegemukan ikan dipengaruhi oleh ukuran, umur, jenis kelamin dan tingkat kematangan gonad ikan yang tertangkap (Sravishta et al., 2018). Nilai faktor kondisi terbesar terdapat pada Ikan Nila (O.niloticus) dengan pola pertumbuhan allometrik negatif. Hal ini diduga penambahan berat Ikan Nila (O. niloticus) tidak hanya disebabkan oleh pertambahan panjang, tetapi juga disebabkan oleh pertambahan tinggi badan. Selanjutnya Aprianti \& Khoirul (2015), menyatakan bahwa perbedaan nilai faktor kondisi dipengaruhi kondisi dan jumlah ikan yang tertangkap. Semakin banyak contoh akan semakin akurat.

\section{SIMPULAN}

Berdasarkan hasil penelitian yang telah dilakukan pada Waduk Penjalin, maka dapat diambil kesimpulan yaitu Pola pertumbuhan Ikan Betutu (O. marmorata) dan Ikan Nila (O. niloticus) bersifat allometrik negatif, sedangkan Ikan Marsela (P. managuensis) bersifat isometric. Nilai faktor kondisi Ikan Betutu (O. marmorata) dan Ikan Marsela ( $P$. managuensis) tergolong dalam memiliki bentuk tubuh yang kurang pipih, sedangkan Ikan Nila (O. niloticus) tergolong memiliki bentuk tubuh agak pipih. Faktor kondisi Ikan Betutu (O. marmorata), Ikan Marsela (P. managuensis) dan Ikan Nila (O. niloticus) termasuk dalam kondisi baik dan dapat untuk dikonsumsi.

\section{UCAPAN TERIMA KASIH}

Terimakasih untuk semua pihak yang sudah mendukung penelitian dan penulisan artikel ini. Serta semua pihak yang memberi kritik dan saran pada penulisan ini sehingga dapat menjadi artikel yang cukup baik. 


\section{REFERENSI}

Adjie, S., K. Fatah, S. Aprianti, S. Gautama, A. Bintoro (2013). Penelitian Perikanan Berbasis Budidaya (Culture-Based Fisheries, Cbf) Di Perairan Waduk Wadaslintang Kabupaten Wonosobo, Jawa Tengah. Balai Penelitian Perikanan Perairan Umum. Kementerian Kelautan Dan Perikanan.

Agasen EV, Julian PC, Mauria RR, Nenita SK. (2006). Biological investigation of Jaguar Guapote Parachromis managuensis (Gunther) in Taal Lake, Philippines. Journal of Environmental Science and Management. 9 (2): 20-30.

Aprianti, S \& Khoirul, F. (2015). Parameter Populasi Ikan Nila (Oreochromis Niloticus) Di Waduk Wadaslintang, Jawa Tengah. Aplikasi Teknologi Sebagai Solusi Di Bidang Perikanan Secara Berkelanjutan. Seminar Nasional Perikanan Indonesia.

Atikah, D., N. Setyaningrum \& Charmudi. (2019). Kekayaan Spesies dan Tingkat Tropik Komunitas Ikan yang Tertangkap di Waduk Penjalin. BioEksata:Jurnal Ilmiah Biologi Unsoed. 1(2) : 56-60.

Brojo, M., S. Sukimin, \& I. Mutiarsih. (2001). Reproduksi Ikan Depik (Rasbora tawarensis) di Perairan Danau Laut Tawar, Aceh Tengah. Jurnal Iktiologi Indonesia. 1(2): 19-23.

Effendie, M.I. (1997). Biologi Perikanan. Yayasan Pustaka Nusatama. Yogyakarta.163p.

Effendie, M.I. (2002). Biologi Perikanan. Yogyakarta (ID): Yayasan Pustaka Nusatama.

Elinah., D. Tumpai F.L \& Y. Ernawati. 2017. Kebiasaan Makan dan Luas Relung Ikan-Ikan Indigenous yang Ditemukan di Waduk Penjalin Kabupaten Brebes, Jawa Tenngah. Jurnal Ilmu Pertanian Indonesia (JIPI). Vol. 21 (2) : 98-103

Fuadi, Z, I. Dewiyanti, S. Purnawan. (2016). Hubungan Panjang Berat Ikan Yang Tertangkap Di Krueng Simpoe, Kabupaten Bireun, Aceh. Jurnal Ilmiah Mahasiswa Kelautan dan Perikanan Unsyiah. 1 (1) : 169-176.

Hamiyati, Iyat. (2016). Upaya Pengendalian Ikan Manila (Parachromis managuensis) Menggunakan Alat Tangkap Jaring Insang di Waduk Penjalin Kabupaten Brebes. Tesis. Bogor (ID): Institut Pertanian Bogor.

Hedianto DA, Kunto P, Andri W. (2013). Interaksi Pemanfaatan Pakan Alami Oleh Komunitas Ikan di Waduk Penjalin, Jawa Tengah. BAWAL. 5(1): 33-40.

Lubis S. (2002). Studi Ekologi Ikan Betutu Oxyeleotris marmorata (Blkr) di Sungai Seruai Kabupaten Deli Serdang Sumatera Utara. Tesis. Universitas Sumatera Utara.

Mahmudah, S., S. Rukayah, I. Sulistyo. (2019). Aspek Pertumbuhan Dan Reproduksi Ikan Betutu (Oxyeleotris marmorata Blkr) di Waduk P.B. Soedirman, Banjarnegara. Prosiding Seminar Nasional Sains Dan Entrepreneurship IV.

Mukhroji \& Y. Suprapto. (2018). Pengembangan Potensi Wisata Air Di Waduk Penjalin Desa Winduaji Kecamatan Paguyangan. Prosiding Seminar Nasional Dies Natalis Universitas Pekalongan Ke-37. Pengembangan Sumberdaya Wilayah Pantura Dalam Rangka Penguatan Ekonomi Kreatif Di Era Revolusi Industri 4.0. ISBN: 978-602-6779-23-6.

Mulfizar, Zainal A. M., Irma D. (2012). Hubungan Panjang Berat Dan Faktor Kondisi Tiga Jenis Ikan Yang Tertangkap Di Perairan Kuala Gigieng, Aceh Besar, Provinsi Aceh. Depik. 1(1):1-9. ISSN 2089-7790.

Muttaqin, Z, I. Dewiyanti, D. Aliza. (2016). Kajian Hubungan Panjang Berat Dan Faktor Kondisi Ikan Nila (Oreochromis Niloticus) Dan Ikan Belanak (Mugil Cephalus) Yang Tertangkap Di Sungai Matang Guru, Kecamatan Madat, Kabupaten Aceh Timur. Jurnal Ilmiah Mahasiswa Kelautan dan Perikanan Unsyiah. 1 (3) : 397-403.

Nasir, M, Z. A. Muchlisin, A. A. Muhammadar. (2016). Hubungan Panjang Berat dan Faktor Kondisi Ikan Betutu (Oxyeleotris marmorata) di Sungai Ulim Kabupaten Pidie Jaya, Provinsi Aceh, Indonesia. Jurnal Ilmiah Mahasiswa Kelautan dan Perikanan Unsyiah. 1 (3) : 262-267.

Putri, M.R.A \& D.W.H Tjahjo. 2010. Analisis Hubungan Panjang Bobot Dan Pendugaan Parameter Pertumbuhan Ikan Nila (Oreochromis niloticus) Di Waduk IR. H. Djuanda.Bawal. 3(2) : 85-92.

Rahardjo, M.F. \& C.P.H. Simanjuntak. (2008). Hubungan panjang bobot dan faktor kondisi ikan tetet, Johnius belangerii Cuvier Pisces: Sciaenidae di Perairan Pantai Mayangan, Jawa Barat. Jurnal Ilmu-ilmu Perairan dan Perikanan Indonesia. 15(2): 135-140.

Rukayah S., \& Wibowo DN. (2011). Komposisi spesies ikan indigenous dan introduksi pada ekosistem Waduk Penjalin Kab. Brebes (acuan: konservasi \& budidaya ikan). Prosiding. Seminar Nasional Hari Lingkungan Hidup. p. 39-48.

Sentosa A. A., D. Wijaya, \& D. W. H. Tjahjo. (2013). Kajian Risiko Keberadaan Ikan-Ikan Introduksi Di Danau Beratan, Bali. Prosiding Forum Nasional Pemulihan Dan Konservasi Sumberdaya Ikan-IV.

Sravishta, I. M. S. K, I. W. Arthana, M. A. Pratiwi. (2018). Pola dan Parameter Pertumbuhan Ikan Tangkapan Dominan (Oreochromis niloticus, Osteochilus sp. dan Xiphophorus helleri) di Danau Buyan Bali. Journal of Marine and Aquatic Sciences. 4(2) : 204-212.

Sulistiono, M. Arwani \& K. A. Aziz. (2001). Pertumbuhan Ikan Belanak (Mugil dussumierf) di Perairan Ujung Pangkah, Jawa Timur. Jurnal Iktiologi Indonesia. 1(2): 39-47.

Syafei, L. S \& D. Sudinno. (2018). Ikan Asing Invasif, Tantangan Keberlanjutan Biodiversitas Perairan. Jurnal Penyuluhan Perikanan dan Kelautan. 12 (3) : 145-161.

Wahyuni, S., Sulistiono \& R. Affandi. (2015). Pertumbuhan, Laju Ekspliotasi Dan Reproduksi Ikan Nila (Oreochromis niloticus) Di Waduk Carita, Jawa Barat. Limnotek. 22(2) : 144-155.

Wargasasmita, S. 2005. Ancaman Invasi Ikan Asing Terhadap Keanekaragaman Ikan Asli. Jurnal Iktiologi Indonesia. Vol 5 (1) : 5-10.

Warsa, A., \& Didik W. H. T. (2019). Estimasi ukuran optimal eksploitasi beberapa jenis ikan di Waduk Jatiluhur, Jawa Barat. Acta Aquatica: Aquatic Sciences Journal. 6 (1) : 13-21. 